\title{
THE WORLD HEALTH ORGANIZATION/WORLD BANK'S FIRST WORLD REPORT ON DISABILITY
}

KATHERINE D. SEELMAN, PHD

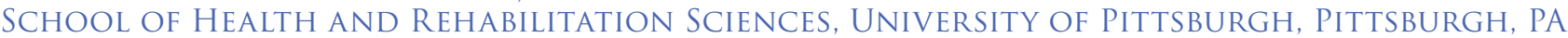

\section{ABSTRACT}

In June, 2011 at the United Nations (UN) in New York City, the World Health Organization (WHO) and the World Bank launched the first World Report on Disability. This short overview of the Report provides information about its purpose, development and content, intended audiences, and outcomes. Special attention is directed to the sections of the Report which address telerehabilitation and information and communication technology.

Keywords: World Report on Disability, telerehabilitation, health information technology

June, 2011 at the United Nations (UN) in New York City, the World Health Organization (WHO) and the World Bank launched the first World Report on Disability.(1) This short overview of the Report provides information about its purpose, development and content, intended audiences, and intended outcomes. The Report is broad in scope but with targeted audiences and intended use. Technology is viewed as an issue cross-cutting all the chapters of the Report. However, within Chapter 5, Rehabilitation, and Chapter 6, Enabling Environments, the significance of telerehabilitation (TR) and information and communications technology (ICT) for individuals with disabilities is examined. These chapters are explored here. They capture the most advanced view of TR and ICT as seen through the lens of the various sections of the international disability community.

\section{PURPOSE}

The Report is one of a trilogy of basic international documents which will guide future disability policy. The most important of these documents is the UN Convention on the Rights of Persons with Disabilities(2) which lays out values, especially human rights, and principles such as accessibility. The second and third documents provide support for the Convention and guidance to policymakers, researchers and others. They are the International Classification of Functioning, Disability and Health (ICF) (3) which is a WHO classification used as a framework for analysis for the Report, and the World Report itself which provides evidence to support the Convention and enlightened policy and practice.

The purpose of the World Report on Disability is to provide robust evidence on which to make well-informed decisions about disability policy and programs. The
Report is intended to provide governments and civil society with evidence on which recommendations for actions are based in areas of policy development, health systems, action on access and attitudes, gaps in research and capacity building. Understanding the numbers of people with disabilities and their circumstances will help national and international policy makers, researchers, professionals, service providers and consumers to improve efforts to remove barriers and provide services. Statistics and research data will help advance the UN Convention on the Rights of People with Disabilities.

\section{PROCESS}

Efforts to produce a World Report on Disability began in earnest in May 2005 when the World Health Assembly adopted Resolution 58.23 on "Disability, including prevention, management and rehabilitation," directing WHO to produce a World Report.(4) The development of the Report was led and managed within the Rehabilitation and Disability unit of the Violence and Injury Prevention and Disability (VIP) section of $\mathrm{WHO}(5)$ in collaboration with staff at the World Bank. The process, which occurred over four years, involved a large number of stakeholders including an advisory and an editorial committee, over 370 contributors and over 70 low, middle, and high income countries. The Report was the subject of extensive reviews and regional consultations. 


\section{CONTENT AND FINDINGS}

The Report is composed of nine chapters covering approaches to disability, prevalence, healthcare, rehabilitation, assistance and support, enabling environments, education, work, and recommendations. The ICF provides the conceptual model. Findings include a higher estimate of disability than WHO's former estimate in the 1970's of 10 percent of the world population. Today, one billion people, 15 per cent of the world population, are estimated to have a disability of which $110-190$ million have very significant difficulties in functioning. The numbers are growing due to aging populations and increase in chronic disease. Not all people are equally disadvantaged with poorer people, women and older people disproportionally affected. These numbers, as well as information about demographic, health and environmental factors affecting trends in disability, can improve efforts to remove barriers and provide services. Disabling barriers include inadequate policies and standards, negative attitudes, lack of provision of services, inadequate funding, lack of accessibility and lack of data and evidence. In turn, barriers contribute to poorer health outcomes, lower educational achievement, less economic participation, higher rates of poverty and increased dependency and restricted participation. Therefore, recommendations include access to all mainstream policies, systems and services, adopting a national disability strategy, funding, involvement of people with disabilities and support for research.

\section{TELEREHABILITATION AND INFORMATION AND COMMUNICATION TECHNOLOGY}

The authors of the Rehabilitation chapter of the Report recognize that TR is an emerging resource that can enhance the capacity and availability of rehabilitation measures by providing interventions and other important resources remotely, thus reaching a vast underserved population. However, availability of the Internet is a concern. Technologies for service delivery include video and teleconferencing, mobile phones and remote datacollection equipment and telemonitoring. The technology may be used by rehabilitation professionals as well as by people with disabilities, therefore accessibility features are important. The chapter provides a number of examples of remote delivery of services such as remote assessments, training and support of health-care personnel, consultations between hospitals for problems related to prosthetics and orthotics and wheelchair prescriptions and sharing professional expertise. Finally, the experts who authored this chapter, like so many others, call for more information on resource allocation and costs to support implementation of TR policy and practice.
The content of the information and communication section of the chapter entitled Enabling Environments departs from the health domain to focus more on the environmental domain. It is particularly sensitive to the relationship between access to communication and information and access to health care, education, local government and justice. The chapter drew from the expertise of agencies and organizations such as the International Telecommunication Union, the G3ict(6) and the UN Global Alliance, the Daisy Consortium(7) and the W3C Web Accessibility Initiative(8) to identify web usage figures, barriers, policies, best practices and to provide recommendations. Technical standards, legislation such as the U.S. 21st Century Communications and Video Accessibility Act, and design principles such as universal design are very much a focus of this chapter.

\section{OUTCOMES}

Many Report-related events, often with educational objectives, are on the international calendar. The World Bank has initiated webinars on the Report.(9) Launches of and symposia about the Report are occurring in countries throughout the world. In the United States, the Report was launched on September 12-13, 2011 in the Washington, D.C. area.(10) The event, sponsored by the Center for International Rehabilitation Research Information and Exchange (CIRRIE), featured a number of well-known leaders. Kareem Dale, Special Assistant to the President for Disability Policy made opening remarks, followed by representatives from the World Bank, World Health Organization and the Pan American Health Organization. Judy Heumann from the U.S. Department of State chaired a panel of departmental representatives who were Obama Administration appointees. Agency and departmental representatives from the Agency for International Development, Education, Health and Human Services and Labor served on panels to discuss the relationship between their work and the content of the Report. The U.S. launch program featured a sequence of panels of authors of each chapter of the Report and discussants who were distinguished scholars, mainly from the U.S. research community, focusing on the relationship between Report content, their work and its impact on their future work. Again in the U.S., the American Academy of Physical and Rehabilitation Medicine (ACRM) featured the Report in its recent meeting and the upcoming Pacific Rim International Conference on Disability \& Diversity (PACRIM) conference will also include a major presentation about the Report. 


\section{CONCLUSIONS}

While these activities and the Report itself are major steps forward in advancing human rights for people with disability, there are issues important to TR that are not addressed in the Report. The international framework for health information technology (HIT) has developed largely independent of the Convention, the ICF and the Report. However, international eHealth documents show increasing sensitivity to the usability of health information technology for end users. An Action Plan for a European eHealth Area was published by the European Commission in April 2004 and endorsed by the EU health ministers in June 2004.(11) The Plan has a code of conduct that includes accessibility criteria, (i.e., "Accessibility - sites should be developed to be as userfriendly as possible for all potential visitors")."(12) There is some indication that individual nations, such as the United States, are beginning to consider the application of accessibility guidelines to HIT(13)(14). If countries use the UN Convention principle of accessibility as a bridge from disability (and aging) to HIT then resulting regulatory requirements may bring TR and other health technology applications into closer alignment with the needs of the disability community.

\section{REFERENCES}

1. World Health Organization World Report on Disability. Accessed October 2011 at http://www.who.int/disabilities/ world_report/2011/en/index.html

2. UN Convention on the Rights of Persons with Disabilities. Accessed October 2011 at http://www.un.org/disabilities/ convention/conventionfull.shtml

3. ICF. Accessed October 2011 at http://www.who.int/ classifications/icf/en/

4. World Health Assembly. WHA 58.23. Accessed October 2011 at http://apps.who.int/gb/ebwha/pdf_files/WHA58/ WHA58_23-en.pdf

5. WHO Violence and Injury Prevention and Disability. Accessed October 2011 at http://www.who.int/violence_ injury_prevention/en/index.html

6. G3ict. Accessed October 2011 at http://g3ict.com/

7. Daisy Consortium. Accessed October 2011 at http:// www.daisy.org/

8. W3C WAI. Accessed October 2011 at http://www.w3.org/ WAI/

9. GLADNET Webinar World Report on Disability. Accessed October 2011 at http://www.gladnet.org/webinar_reg.cfm

10. CIRRIE. Accessed October 2011 at http://www.gladnet. org/webinar_reg.cfm

11. Health Information Technology Global Perspectives. Accessed October 2011 at http://www.openclinical.org/ hitGlobalEuropeEU.html

12. Information e-health quality criteria. Accessed October 2011 at http://ec.europa.eu/information_society/ activities/health/policy/quality_criteria/index_en.htm

13. DBTACs Webinars. Accessed October 2011 at http:// www.access-board.gov/webinars.htm

14. WGBH/NCAM awarded "Access to Personal Health Records" grant. Accessed October 2011 at http://ncam. wgbh.org/about/news/healthitaccess 
